\title{
Universal Situation as a Literary-Semantic Phenomenon: On the Example of Works by N.S. Leskov
}

\author{
Natalya N. Starygina \\ Inna N. Mikheeva \\ Olga S. Berezina \\ Marina A. Pershina \\ Irina K. Klyukha \\ Mari State University, Yoshkar-Ola, Russia \\ Email: marja8362@mail.ru
}

\section{Doi:10.5901/mjss.2015.v6n3s7p91}

\begin{abstract}
The starting point of the research was the understanding of the fact that a literary work is created and exists in a particular social and cultural area and that a writer is guided by existential universals, eternal themes, motives, images, typological genre components and poetical means. The individual style of an author is revealed by the presentation of universal situations and his perception of them. In the works by N.S. Leskov the key universal situations are transfiguration of a person and the world by a righteous man, leaving home and a comeback, deception. The realization of a universal situation of transfiguration of the world and a man are impossible without some righteous activity performed by characters. Righteous characters are able to increase their spiritual grace and with the help of it to transfigure space and time, the world and mankind. The situation of leaving and coming back home is connected with Leskov's idea that a home is a place which is full of peace, coziness. It correlates with the concept of a home in Russian culture and is the basis of the author's world vision peculiarities. Referring to such situation the writer illustrates the degradation of a person who has lost his home as well as his renunciation of roots and loss of moral landmarks. The universal situation of deception in Leskov's Christmas tales has an effect of a distorting mirror, a change in value landmarks (from material and spiritual), moral lesson that highlights the axiological perception of the writer.
\end{abstract}

Keywords: Leskov, literary universals, universal situations, home, transfiguration, deception

\section{Introduction}

People live in the world of common concepts and statements or the so-called universals (lat. universalis - common) which are the result of mental constructing: description, analysis, and generalization. The basis of this process is supervision of the real life of a person.

V.O. Klyuchevskiy writes that there is "a group of those mental and moral concepts and interests which are no longer products of mental activity of some individuals and their minds but common property of all mankind" (Klyuchevskiy, 1987). It is "practical processing of ideas which is a part of the whole historical process" (Klyuchevskiy, 1987).

In other words, in any sphere of human knowledge there are general notions revealed in terms. Traditionally scientists consider: the sphere of ontological (existential and common) universals, anthropological universals (features that are typical for all mankind in general), the sphere of national-mental universals ("mental substances": honor, justice, truth, fate, happiness, peace, will (Volodina, 2010), mythological and archaic universals (general basics of the collective unconscious mind of human psyche, common for all mankind and fundamental mythological motives, universal mythopoetical schemes, "schemes" of images, "schemes" of plots, genre urforms and etc.), universals of Russian spirituality (Christian, religious), social and cultural, linguistic universals (features common for all languages or the majority of them) or linguistic phenomena that can be found in all or the majority of languages (nouns, verbs, pronouns, category of number, etc.) (Vezhbitskaya, 1990).

They also consider translation universals (concepts and categories of translation which exist regardless of conditions of translation, genres of texts and languages used). Translation universals are an invariant, a message, methods of translation, equivalents, units of translation and etc., non-verbal (behavioristic) universals (movements, 
gestures, etc.) and so on.

The most developed are linguistic universals and the conception of cultural universals. In the study of literature there are few definitions of a rather popular and frequently used concept "literary universal". A writer and a critic respectively can observe all things that are connected with human life and human knowledge - thus all the universals: existential, anthropological, social, cultural, etc. In this case it is important to understand that a literary universal is a textual phenomenon which has its own structural and semantic expression and general (common, universal) form. Thus literary universals are structural and semantic phenomena that are common to literary works and that received conceptual notation in the study of literature. The closest to this definition is the definition given by L.I. Emelyanov: Literary universals are "plot and characterological "formula" which have existed in literature since folklore and ancient literature. Historical movement of universals is a different degree of quantity transferred into a new quality, new "semantics", expressing a universal only morphologically" (Emelyalov, 1981). A literary universal has a universal content and contains universal idea and concept (e.g. sin), which also has universal expression in a literary work (e.g. a motive of sin, a plot of fall, an opposition sinful/righteous). So universality is given to this literary phenomenon by two universal factors: a) idea, b) method (or means) of its expression (motive). The result is a literary universal: a motive of sin, a plot of fall, an opposition sinful/righteous and etc. - or a particular structural and semantic phenomenon of a literary text. Its scientific notion will include a term (referring to its form in a text) and a concept or a word-concept (referring to its semantics). Universality of a phenomenon is proved by its constant existence in literary works of different times.

In literature a particular number of general motives which meaningful content can be expressed by, for instance, a concept have been formed. The variety of these motives in a text is revealed through the usage of similar poetical means, while their importance is shown by their plot-forming function. The group of universal motives includes ontological motives (of fate, life and death, birth, growing-up, immortality, etc.), anthropological (of will, happiness, madness, etc.), mythological or archetypical (transfiguration, way, etc.), folk (kidnapping, fighting, etc.), religious (righteousness, sin, repentance, etc.), national and mental (of soul, peace, will, Russia), chronotopical (of travel, search, comeback, etc.).

The most various is the typology of universal images (literary universals): images-concepts (types of characters), images-characters, images-symbols, images-emblems. Each image group may have its own typology. Images-characters are a "superfluous man", "dreamer", "practitioner", "new man", "small man", etc. Images-characters are a lover, a warrior, a righteous man, a sinner, etc. Images-symbols are sound, colour images as well as national, social, religious, cultural images and images of arts, nature, space, time, etc. Images-emblems are nature-images (a branch of lilac, a pigeon), human images and etc. Literary universals are also images of an author and a reader which characterize peculiarities of a literary text as an utterance-result: the subject of the utterance is the author (his image exists in the text), the subject of perception is the reader (his image exists in the text as well).

In any literary work it is possible to find universal situations which will characterize a unique (particular) plot. A situation as a literary universal has a real "prototype": a situation that is universal in a life of a person. This is a situation of communication, an ontological situation, a situation of reading, listening to music or looking at art works, a situation of acquaintance, a sacral situation, etc. Such typology of situations is necessary because the expression of any particular situation depends on a topic, a character, a plot of a literary work.

Thus a literary work is created and exists in a particular social and cultural area and each writer is guided by existential universals, eternal themes, motives, images, typological genre components and poetical means. The ways of literary perception of the world, common for writer of all epochs, are uniquely revealed in a particular historical period in the works of different authors. That is why the analysis and description of means of literary thinking is one of the most important research topics in the modern study of literature.

\section{Discussions and Results}

The researches of the works by N.S. Leskov have already studied several problems of literary universals: separate group of eternal (or "timeless") images borrowed from the English literature (Pershina, 2012), universal images and motives (Starygina, Pershina, Mikheeva, Berezina, Klyukha, 2015). A universal situation as a literary-semantic phenomenon has been studied yet. Athough universal situations exactly as the characteristics of a universal plot reveal individuality of the writer.

There are three universal situations which are the most important for the works of N.S. Leskov: 1) the situation of transfiguration of the world and a person by a righteous man, 2) the situation of leaving home and coming back, 3) the situation of deception. 


\subsection{The situation of transfiguration of the world and a person by a righteous man}

In their literary works in general and especially during some significant historical changes writers try to understand the events of their time and evaluate them. N.S. Leskov did his best opposing widely spread destructive conceptions of nihilism that time, "trying to find a moral basis in a particular person which is an example of brave confrontation of harmful spirit of his time" (Stolyarova, 1992). Also the theme of righteousness appears in his works. The writer's conception of righteousness is based on the most important idea of Christianity - the idea of saving a man. Through kindness, sympathy and mercy a righteous man saves himself and all the mankind attempting to make the Earth closer to Heaven. A light-bringing person "touching the world makes it a part of Beauty which part he became himself during his ascetic deed of valor" (Martynov, 2000). Creating images of righteous people Leskov connects them with the ideas of creation and transfiguration of the world and a person. Thus a situation that is universal for his works appear. This is a situation of transfiguration of the world and a person by a righteous man. It correlates with a literary universal of transformation which is typical both for Russian (Garicheva, 2009) and world literature as a whole.

The final purpose and sense of transfiguration of the world by a righteous man for the writer is a person. In the works of N.S. Leskov transformation is aimed at the world around and, as a result, at a person.

In the tale "Odnodum" the main character Aleksadr Afanasevich Ryzhov is appointed to the position of the governor of the town. Due to it transfiguration of the whole town happens: "Ryzhov walks through the town in the afternoon and walks alone at night, and little by little his kind master's supervision can be found everywhere" (Leskov, 1989: Odnodum, 12). The narrator compares the town before Ryzhov's election and after it: e.g. changes in a life of the town during the arrival of a district governor. That time the town and its suburbs were usually full of great vanity but Ryzhov changed everything. "He behaved as he did not care about the coming event at all. He did not break any fence of any citizen, did not paint anything with ochre or chalk and did not do anything at all to decorate the town and his own insufficient dress" (Leskov, 1989: Odnodum, 24). Regardless of other governors of towns he transfigured everything around with his "kind master's supervision and order". Waiting for a district governor arrival Ryzhov discussed it with citizens, while the rest governors of towns cared only about themselves. Thus the transfiguration of the town was not the change in favour of the change itself but of its citizens. That is why deeds of Ryzhov are appreciated by people and are the example of "the active good".

In the tale "Cadet Monastery" the conception of a clerical institution is put on the structure of an educational institution and its spirit is reflected in the world mapping of characters and their images. Students make a spiritual unity with their tutors learning morals values and using them in their life: "I will shortly tell about those who taught us and how they did it, i.e. which traits of their character and example found reflection in our souls and hearts because being a sinful man without this lively elevating feeling of example I did not understand any upbringing" (Leskov, 1989: Cadet Monastery, 48). Sharing care, attention, love the righteous characters Perskiy, Bobrov, Zelenskiy, father archimandrite transfigure not only the inner space of the institute but the inner world of their student as well.

However, the impact on the world and people is made not only by the righteous men. The influence of the righteous men correlates with transfiguration, while the influence of antagonists - with damage. Penetrating into a harmonious world antagonists destroy its usual life. For instance, with the election of Demidov on the position of the director of this institution the narrator begins to pay attention to the march of time that has not been noticed yet: "next day", "in a week", "next Sunday". The march of time gets notable because the events (the demotion of cadets into corporals, the resignation of the archimandrite) destroy the usual life of the institution and its formed morals and values. Changes in the system of upbringing brought with the election of Demidov caused changes in the spatial pattern of the cadet institution: "special punishment cells" appeared, the museum and library were closed. However, the attempt to destroy the idyll of cadet monastery turns to be only formal; it cannot demolish the inner spiritual bases which have been taught in students' hearts by their righteous tutors.

Like righteous men in the cadet monastery the main character of the tale "Russian democrat in Poland" I.F. Samburskiy is a constructive person who is able to transfigure the world around. His official task in Poland was "to return the Russian ruling instead of the revolutionary one; to reveal incomes and organize good congregation and circulation of capital. In general it was a case which needed good organization after the chaos caused by the military revolution" (Leskov, 1989: Russian democrat in Poland, 80). Like righteous characters he managed to create conditions that helped him to organize the world according to his point of view and principles. That is why his chancellery receives some feature of family idyll. He filled the government institution with family warmth and improved official relations with such values as domesticity, "heat in a heart and love to all mankind", patriotism. Samburskiy is able to keep to these moral principles himself and teach his subordinates: "teaching us to be modest just in case, without any warning" (Leskov, 1989: Russian democrat in Poland, 83). 
N.S. Leskov considered both ethical and moral features important in images of his righteous characters. In the tale "Engineers - Disinterested People" the author compares the fate of three characters: D. Bryanchaninov, M. Chikhavech and $\mathrm{N}$. Fermor. Although all of them were students of one engineering college, the axiological principles of Bryanchinov and Chikhachev were "to protect themselves from pride", to save the purity of hearts, to avoid "fury, lie, irritability, vengeance and flattery" for what you "always need to look at the Godman" (Leskov, 1989: Engineers - Disinterested People, 139). Bryanchaninov and Chikhachev are constructive images; they are capable of transforming the world and people: in the college they organized a group of lovers and fans of "holiness and honor" and inspired students were eager to join it. However, their follower Fermor is unable to transfigure the world. On the contrary, his behavior irritates people around. Despite the moral principles of Bryanchaninov and Chikhachev the most important in his perception of the world are ethical values: honesty and nobility which he appealed to and summoned the others. Eventually these calls turned to be vain and his moral maximalism led Fermor to extreme disappointment. Looking for the meaning of life in ethical values and failing to find it, he lost the value of his life and his dream of changing the world that turned to be unrealizable led him to self-damage.

Thus, realization of a universal situation of transfiguration of the world and a man is possible for N.S. Leskov without a character's ascetic deed of valour, i.e. without success in the active virtue in favour of the God. The inner spiritual organization of righteous characters is some kind of immunity which protects them from harmful influence of the world. The liability to this phenomenon and its degree depends on the personality of Leskov's characters. Righteous characters are able to save and increase their spiritual grace and with the help of this to transform space and time, the world and a man.

\subsection{The situation of leaving home and coming back}

A good example of this type of universal situations is the novel "At Daggers" (1870-1871). The roots of the plot are the biblical parable of the prodigal son and the Russian folk tradition (a motive of prohibition of leaving one's native house). In the novel by N.S. Leskov the Vislenevs brother and sister leave their father's house and renounce it. Since that moment their live changes completely. Iosaf loses all money for their pawned house playing roulette, Lara wastes abroad all money found by their friend Podozerov for redemption of the house. The writer shows that with a loss of the house and home lives of the Vislenevs family lose spiritual values, moral ideals, and dignity. All further attempts to find another home are useless, these houses are fake homes. The feeling of a fake home increases with the appearance of a house of Glafira Bordostina in the novel. It is compared with "a crystal cage which stands on top of a rock where high wind blow". This image approaches the universal image of a house-prison. Even Ropshin who suffers from love yearning has a feeling of imprisonment in Bodrostina's house which is "unfriendly and terrible" and is usually called "a drag-net": "Found himself in this old, rich mansion Ropshin was immediately caught by drag-nets which were placed here in all the corners" (Leskov, 2015).

The situation of leaving home in the novel corresponds with universal folk motives of kidnapping a bride from her father's house and snake/evil fight. The image of the tempter in the novel is represented by Pavel Gordanov. He kidnaps "a beautiful bride" Lara from her home, seduces her and breaks with her. The hero-character is Podozerov who tries to save Lara. The image of Podozerov can be considered as universal as it contains typical features of the archetypical character image: He experienced severe hardships as a child and his past is connected with the legend of the Spanish nobleman told by Vodopyanov.

Comparing the image of Lara, a character "at the cross roads" (Starygina, 1998) with an ideal, from the author point of view, image of Aleksandra Sintyanina - a savior, comforter, home keeper (Berezina, 2015) - Leskov as a Christian writer introduces to the plot a universal situation of praying that fully characterizes his female characters. The prayer of Aleksandra is "anxious and passionate": "She could not pray in a quiet way" (Leskov, 2015), while Lara in her appeal to the Lord forgets the words of the prayer: "She turned to an icon, knelled, burst into tears and began praying with her aunt's words but suddenly forgot them" (Leskov, 2015).

In the works of N.S. Leskov a house is a means of characteristics: a character's love to his/her house reveals his/her personality. For instance, Lara who easily sells her house is opposed to Aleksandra Sintyanina whose house is her entire world. A small mansion in Pochinka ("A small house with two tiny rooms: a dining-room and her daughter's bedroom... Nothing special: a tiny garden, a small pond, a mill, an asp forest, chestnut bushes, a lot of cattle and a small field, that is all" (Leskov, 2015)) is a part of the nature. A poetic cottage - a favourite place of the majority of characters in the novel - is always open to visitors.

Feeling hostility as all other characters in Bodrostina's house: "It seemed that she was a captive, a prisoner" (Leskov, 2015), Lara strives to come back home: "Her own house seemed as a paradise lost once and forever" (Leskov, 
2015). This episode reveals the situation of character's coming back to her father's house. It shows pity for previous actions and glad for meeting with relatives and friends: "Found herself in the house of the general, for the first time in her life Lara had that wonderful feeling which comes to one's heart when he meets his family while he thought that he had lost it once and forever. Lara embraced Aleksandra Ivanovna and kissed her several times; then she did the same with her aunt Forova" (Leskov, 2015). However, she did not manage to find harmony in her heart and decided to trust Gordanov again that led to a duel between Gordanov and Podozerov, and then she married Podozerov but finally left him, left home and died in an unfriendly forest. This image, according to Y. Lotman, is "anti-home", "a forest house" (Lotman, 1999). Home is opposed to chaos and external destructive influence.

losaf did not manage to return happily to his father's house either. He lost his house and was spending his live renting cheap apartments or hotel rooms or living in his friends' houses of Kishenskiy and Bodrostin. Eventually he found peace only in a lunatic asylum.

Leskov's conception of a house as a place where there is an atmosphere of peace and coziness correlates the concept of a house in traditional Russian culture and proves some particularities of the author's world viewing. On the example of universal situations of leaving home and useless attempts to come back the writer shows the degradation of personality with the loss of a house, renunciation of roots and loss of moral principles that without true and deep repentance leads to a dismal end.

\subsection{The situation of deception}

The situation of deception is universal for the world literature. In myths and fairy tales characters often cheat to win their opponents. In literature deception is usually treated both as a harmless practical joke and as a cunning craft to achieve one's goals.

In the works by N.S. Leskov the universal situation of deception receive special features. For instance, in Christmas tales it is determined by the particularities of the genre: "it is a bit fantastic, extirpates a prejudice, and has not a sad one but a cheerful ending" (Leskov, 1989: Pearl Necklace, 4). In his works there is always an aim to make events true or the basis of a story is an interesting case and the situation itself always contains a moral sense.

A good example of the situation of deception is the tale of the same name "Deception". The basis of the tale is buffoonery, practical joking and cheating. The story is narrated by the deceived character who is shocked with this "joke": he was looking for love of a married lady unknown to her husband, but the husband turned to be slier - he secretly changed his wife to another woman who was selling her love. The narrator is indignant but the reader understands that the author is not for him. This is the method of the reverse when everything is inside out and back to front and the world is shown with all its anomalous values and moral principles as a distorting mirror.

Another situation of deception is depicted in the tale "Pearl Necklace". In the center of the story there is a present given by Nikolay Ivanovich to his daughter on the New Year eve. It is a pearl necklace which was presented suddenly, in public with great pathos: "He put on her an expensive pearl necklace himself in public" (Leskov, 1989: Pearl Necklace, 12). Guests had different reaction. Men began to guess the price of the necklace: "My goodness! It must cost a fortune. It was probably recondite long ago when rich people did not send their possessions to pawn-shops and trusted secret money-lenders like Mary's father... we all, brute men, found Mary's present wonderful" (Leskov, 1989: Pearl Necklace, 12). On the other hand, women were rather negative about this present. Mary burst into tears and her mother and wife of Nikolay Ivanovich admonished him for this because pearl had always been considered a bad luck. However, Nikolay Ivanovich himself disagreed with them: "This is, my dear daughter, an incantation thing: it can be neither spoilt, nor stolen. Even if someone steals it, it won't bring him joy. This is eternal" (Leskov, 1989: Pearl Necklace, 12). The necklace symbolized a test for a family. Nikolay Ivanovich examines the groom on love to his daughter and gives as a dowry a necklace made of artificial pearl which is presented as true one. The present is forgery and provocation that is used intentionally by the character in the situation of testing. On the one hand, the father of the bride presented his daughter with an artificial jewelry to learn the intensions of the groom: whether they are greed or of true love; on the other hand, to reveal his son-in-law-to-be's personality and moral principles. Deception hid spiritual value under the material one.

The situation of deception in the tale "Travel with a nihilist" is transformed in the situation of self-deception. The plot is built around the case of misunderstanding: several passengers picked a prosecutor who was traveling in the same compartment for a nihilist. The appearance of this strange passenger, according to the narrator of the story, was rather similar to other passengers' view on nihilists: "round glasses, an ill-intentioned cap with a form of not an Orthodox pancake but with a heterodox hummock and a typical rug blanket on the shoulders that together in the nihilist class form some kind of 'a uniform pair'" (Leskov, 1989: Travel with a nihilist, 171). Moreover, a stranger did not want to pack in the baggage his small basket and said abruptly "I do not want" several times even if it was not permitted to keep it with him. 
Passenger considered it as one more display of nihilism - negation of common rules and norms. Thus "the nihilist" himself did not have any intention to deceive passengers as he did not communicate to them. Fear for nihilism caused the situation of self-deception as a result of which the reality was distorted.

Fear as a reason of self-deception is depicted in the tale "Ghost in the Engineering Castle". The students of the cadet institution picked a sick widow of the dead general Lamnovskiy for a ghost. Fear of death, fear of the severe general and the legend of the ghost that lived in the institution played Old Harry with the cadets. The widow herself was at the death door but the incredible power of love helped her to come to pay a last tribute to her husband. However, a mystical image of the ghost was created rather realistically in the imagination of students: the widow was dressed in white, with white flowing hair (it scared them even more and created an image of a witch), unpleasant rustling that cadets picked for the rustling of sleeves of the dead was her touching the walls. Traditionally ghosts are depicted as white or transparent figures. Beside the white clothes an episode with the arrival of 'the ghost' correlates with the attributes of death: a coffin with the dead, night, a scary legend. The revealed self-deception shamed the cadets of their joy that the general was dead and taught them the true value of love: "After this event for all of us it was revolting to hear that someone was cheerful on one's death. We always remembered our prank and the holy hand of the last ghost of the Engineering Castle which was the only one who had a power against us by the right of true love" (Leskov, 1989: Ghost of the Engineering castle, 56).

Thus the universal situation of deception in Christmas tales of N.S. Leskov may have an effect of a distorting mirror, a change of values (from material to spiritual ones) and a moral lesson.

\section{Conclusions}

Universal situations can be found on different levels of a literary text: problematic (the situation of leaving one's home and coming back refers to eternal themes and motives of home and family), image-bearing (the situation of transfiguration of the world and a person by a righteous man refers to the concept of "righteous man"), poetical (the situation of deception is specifically revealed in a concrete genre form). The study of their formation and existence requires the analysis of the literary text in historical-literary and social-cultural context, examination of its intertextuality and its mythological 'code' decoding, as well as actualization of historical-genitive and comparative-typological methods.

\section{References}

Berezina, O.S. (2015). Peculiarities of the Slavophil conception of shelter in works of N.S. Leskov (in the novel "At Daggers"). Vestnik of Mari State University. No 1 (16). Pp. 65-68.

Vezhbitskaya, A. (1990). Semantic universals and description of languages. Moscow.

Volodina, N. (2010). Concepts, universals, stereotypes in the sphere of the study of literature. Moscow: Flinta-Nauka.

Garicheva, E.A. (2009). Phenomenon of transformation in the Russian literature of the XVI-XX centuries. Sysnopsis of a dissertation: 10.01.01. Moscow. $44 \mathrm{p}$.

Emelyanov, L.I. (1981). Study of literature and folklore. Interaction of sciences in the study of literature. Leningrad. Pp. 102-130.

Klyuchevskiy, V.O. (1987). Course of the Russian history. Collected works: in 9 vol. Vol. 1. Moscow. P. 56.

Klyuchevskiy, V.O. (1987). Course of the Russian history. Collected works: in 9 vol. Vol. 1. Moscow. P. 55.

Leskov, N.S. (1989) Collected works: in 12 vol. Moscow. Vol. 2, 7. The names of works, cited from this edition, as well as pages are given after the name of the author.

Leskov, N.S. (2015). At Daggers: novel. [Online] Available: http://fanread.ru/book/731860/ (06.05.2015).

Lotman, Y.M. (1999). Inside of thinking worlds. Man - text - semiosphere - history. Moscow. P. 264-265.

Martynov, V.I. (2000). Culture, iconoshpere and liturgical singing in Muscovite Russia. Moscow. P. 27.

Mikheeva, I.N. (2009). Hierarchical world modeling as a method of realization of the conception of righteousness in the works by N.S. Leskov. Vestik of St. Petersburg University. Vol. 9. Philology. Oriental studies. Journalism. № 3. Pp. 77-85.

Novikova-Stroganova, A.A. (2013). Chrismas tales of N.S. Leskov. [Online] Available: http://www.bogoslov.ru/text/3064355.html (09.05.2015).

Pershina, M.A. (2012). "Timeless images" of the English literature in the works of N.S. Leskov. Vestnik of Chuvash University". No 8. Pp. 295-301.

Starygina, N.N. (1998). Female images in the context of Christian teaching of soul dispensation ("Breakage" by I.A. Goncharov, "At Daggers" by N.S. Leskov, "Demons" by F.M. Dostoevsky). Open literature lesson: book for teachers. Vol. 2. Moscow. P. 198.

Starygina, N.N., Pershina, M.A., Mikheeva, I.N., Berezina, O.S., Klyukha, I.K. (2015). Dickens' Christmas Story as an Intertexteme in Leskov's Yule Short Story. Review of European Studies, Vol 7, No. 8. Pp. 193-200. DOI: 10.5539/res.v7n8p193

Stolyarova, I.V. (1992). N.S. Leskov and Russian literary-public movement in 1880-1890-s.: Sysnopsis of a dissertation: 10.01.01. St. Petersburg. P. 9. 